\title{
Immune response in Lutjanus erythropterus induced by the major outer membrane protein (OmpU) of Vibrio alginolyticus
}

\author{
Shuang-Hu Cai ${ }^{1,2}$, Shao-Yun Yao ${ }^{1,2}$, Yi-Shan $\mathrm{Lu}^{1,2}$, Zao-He $\mathrm{Wu}^{1,2}$, \\ Ji-Chang Jian ${ }^{1,2, *}$, Bei Wang ${ }^{1,2}$ \\ ${ }^{1}$ Fisheries College, Guangdong Ocean University, Zhanjiang 524088, China \\ ${ }^{2}$ Guangdong Provincial Key Laboratory of Pathogenic Biology and Epidemiology \\ for Aquatic Economic Animals, Zhanjiang 524088, China
}

\begin{abstract}
The outer membrane proteins (OMPs) of the marine aquatic animal pathogen Vibrio alginolyticus play an important role in the virulence of the bacterium and are potential candidates for vaccine development. In this study, the major $35.6 \mathrm{kDa}$ OMP of $V$. alginolyticus was isolated by gel excision from the crude OMP fraction from $V$. alginolyticus. The sequence of the first 27 amino acid residues from the N-terminal end of the protein is ATV YKD GGT ELL VGG RVE FRG DFI GSD, which has high homology with OmpU proteins from other Vibrio spp. (92\%). Lutjanus erythropterus were vaccinated with $\mathrm{OmpU}$, and immunogenicity was confirmed by subsequent western blotting. Enzyme-linked immunosorbent assay (ELISA) analysis demonstrated that OmpU produced an observable antibody response in all sera of the vaccinated fish. L. erythropterus vaccinated with OmpU produced specific antibodies, and were highly resistant to infection with virulent $V$. alginolyticus. These results indicate that $\mathrm{OmpU}$ is an effective vaccine candidate against $V$. alginolyticus for L. erythropterus.
\end{abstract}

KEY WORDS: Vibrio alginolyticus $\cdot$ Outer membrane protein $\cdot$ OmpU $\cdot$ Immunogenicity $\cdot$ Vaccine

\section{INTRODUCTION}

Vibriosis is one of the most prevalent diseases in marine aquatic animals (Egidius 1987, de la Pena et al. 1993). Various Vibrio species have been identified as opportunistic pathogens that cause serious production losses in fish, shrimp and shellfish farms with mortality up to $100 \%$, particularly in juvenile populations (Prayitno \& Latchford 1995, Vandenberghe et al. 1998). Vibrio alginolyticus is one of the major Vibrio pathogens causing clinical signs of bacterial septicemia and skin ulcers in marine animals (Lee et al. 1996a, Zorrilla et al. 2003, Cai et al. 2007). Control of vibriosis through antibiotic treatment is not always successful and could be hazardous for the environment since resistant bacteria may be selected and the resistance may be trans- ferred to aquatic animal or human pathogens. Therefore, the development of vaccines to protect aquatic animals against vibriosis is important (Kumar et al. 2007, Khushiramani et al. 2007, Li et al. 2008). Some virulence factors may contribute to the overall virulence of $V$. alginolyticus. These include extracellular products, endotoxins and adhesins (Lee et al. 1996b, $\mathrm{Xu}$ et al. 2005).

The outer membrane proteins (OMPs) of Vibrio are important adhesion factors. They are basically composed of protein, lipid and sugar, which could be easily recognized as foreign substances by the host's immunological defense systems (Qian et al. 2007). These OMPs play an important role in infection and pathogenicity in the host (Tsolis 2002). They possess high hydrophobicity, which is one of the important 
forces that macromolecules use to preserve their binding interactions. Therefore, OMPs can adhere to mucosal membranes, and antigen-presenting cells of gut-associated lymphoid tissues (GALT) can easily present OMPs as antigen to immune cells (Gordon \& Alistair 1992). The OMPs of Vibrio are bile resistant and stimulate biofilm formation (Wang et al. 2003). Resistance to bile is important for bacteria to colonize the intestine of the fish host and biofilm formation provides an adaptive and survival advantage for bacteria in an aquatic environment (Olsson et al. 1996, 1998). The major OMP may be useful as a component of a Vibrio vaccine and also for diagnostic purposes (Jung et al. 2005, Hong et al. 2009).

The pathogenesis of Vibrio alginolyticus consists of gaining access to the host tissue, colonization and invasion. During colonization, surface materials of the organisms, such as lipopolysaccharide and OMPs, play an important role in the adhesion to host cells (Cheng et al. 2005, Hong et al. 2006). OMPs of Vibrio and their role have been mainly studied in $V$. cholerae (Sperandio et al. 1995), V. anguillarum (Waldbeser et al. 1993), $V$. vulnificus (Litwin \& Byrne 1998) and V. fischeri (Aeckersberg et al. 2001), but there are very few reports on the immunological characterization of the major OMP from $V$. alginolyticus.

\section{MATERIALS AND METHODS}

Bacteria and culture conditions. Vibrio alginolyticus strain HY9901 was isolated from the diseased maricultured fish Lutjanus erythropterus at Zhanjiang, China. The isolate was preserved in Tryptone Soya Broth (TSB, Huangkai) supplemented with $2 \% \mathrm{NaCl}$ and $20 \%$ glycerol at $-80^{\circ} \mathrm{C}$. The culture was retrieved on Tryptone Soya Agar (TSA, Huangkai) plates supplemented with $2 \% \mathrm{NaCl}$ incubated at $28^{\circ} \mathrm{C}$.

Crude OMP extraction. Isolation of OMPs was carried out using the method of Hamid \& Jain (2008). The bacteria were harvested and washed 3 times with $10 \mathrm{mM}$ Tris- $\mathrm{HCl}$ ( $\mathrm{pH} 7.5$ ), and $1.0 \mathrm{~g}$ (wet weight) of bacteria was extracted with $20 \mathrm{ml}$ extraction buffer (10 mM Tris-HCl, pH 7.5, 10 mM EDTA, $6 \mathrm{M}$ urea) for $1 \mathrm{~h}$ at $4^{\circ} \mathrm{C}$. The extract was dialyzed against distilled water for $3 \mathrm{~d}$ with frequent changes. The dialyzed material was centrifuged at $5400 \times g$ for $1 \mathrm{~h}$ at $4^{\circ} \mathrm{C}$, and the supernatant was collected and lyophilized with a lyophilizer (PowerDry PL3000 Freeze Dryer, Heto). The crude OMP extract was stored at $-20^{\circ} \mathrm{C}$ until further use.

Sodium dodecyl sulfate polyacrylamide gel electrophoresis (SDS-PAGE) of crude OMPs. Protein samples were solubilized in Tris- $\mathrm{HCl}$ buffer supplemented with $2 \%$ sodium dodecyl sulfate (SDS) and 5\% mer- captoethanol, and boiled at $100^{\circ} \mathrm{C}$ for $5 \mathrm{~min}$. SDSPAGE was carried out on a $12 \%$ separating gel with the discontinuous buffer system as described by Laemmli (1970). The gels were stained with $0.1 \%$ (wt/vol) Coomassie brilliant blue R-250 (Sigma) in $45.4 \%$ (vol/vol) methanol and $9.2 \%$ (vol/vol) glacial acetic acid, and destained with $5 \%$ (vol/vol) methanol and $7 \%$ (vol/vol) glacial acetic acid. The protein content of the crude OMPs was estimated using the method of Lowry et al. (1951).

Isolation and $\mathrm{N}$-terminal amino acid sequence of 35.6 kDa OMP. The crude OMP preparation was fractionated on a preparative (3 mm thick, 12\%) SDSPAGE gel using the method of Hamid \& Jain (2008). The 35.6 kDa OMP band was located by careful calculation of relative mobility values vis-à-vis the values for protein weight markers. The $35.6 \mathrm{kDa}$ OMP band was excised from the gels, crushed finely, suspended in 2 volumes of elution buffer $(0.025 \mathrm{M}$ Tris- $\mathrm{HCl}, \mathrm{pH} 8.3$, $0.192 \mathrm{M}$ glycine, $6 \mathrm{M}$ urea), and incubated overnight at $4^{\circ} \mathrm{C}$ on a rocking platform. The supernatant was collected, and the gel pellet was re-extracted. The 2 supernatants were pooled, dialyzed at $4^{\circ} \mathrm{C}$ against distilled water to remove urea, and then lyophilized. The concentration of eluted protein was estimated using the method of Lowry et al. (1951), and its purity was assessed by SDS-PAGE and silver staining (Blum et al. 1987).

The $35.6 \mathrm{kDa}$ protein (OmpU) was subjected to $\mathrm{N}$ terminal sequence determination with an Applied Biosystems automated sequencer. This analysis was kindly performed by Shanghai GeneCore BioTechnologies, Shanghai, China.

Preparation of antiserum against Vibrio alginolyticus and the isolated OmpU. Antiserum against $V$. alginolyticus was raised in New Zealand white rabbits by injecting $2 \times 10^{5}$ colony forming units (CFU) of live bacteria in phosphate buffered saline (PBS, $10 \mathrm{mM}$, $\mathrm{pH}$ 7.2). All rabbits were boosted 4 wk later with the same antigen preparations. Four weeks after the booster injection, the rabbits were bled and the blood was clotted at room temperature for $1 \mathrm{~h}$ and then stored at $4{ }^{\circ} \mathrm{C}$ overnight. The antiserum was used for western blot analysis.

Antiserum against the isolated OmpU was prepared according to the method of Khushiramani et al. (2007). This antiserum was used for analysis of antibody levels.

Western blot analysis. The crude OMPs from whole cells of Vibrio alginolyticus and the isolated $35.6 \mathrm{kDa}$ OMP were electrophoresed by SDS-PAGE, using a $5 \%$ stacking gel and a $15 \%$ separating gel. The proteins were electrically transferred to nitrocellulose paper (0.45 mm pore size, Bio-Rad) using a semi-dry apparatus (Bio-Rad) as described by Towbin et al. (1979). The sera from rabbits vaccinated with $V$. alginolyticus were 
used as primary antibody at a 1:100 dilution. The secondary antibody was peroxidase-conjugated goatanti-rabbit IgG (Sigma) used at a 1:5000 dilution. The antibody-bound proteins were then visualized by 3, 3'diaminobenzidine (DAB).

Vaccine preparation and vaccination. The isolated OmpU (1 $\mathrm{mg} \mathrm{ml}^{-1}$ ) and sterile PBS (10 mM, pH 7.2) were each emulsified with an equal volume of Freund's incomplete adjuvant (Sigma). Lutjanus erythropterus weighing approximately $50 \mathrm{~g}$ were randomly divided into 2 groups with 70 fish in each group. Vaccination group was immunized by intramuscular injection with emulsified OmpU, and the control group with emulsified sterile PBS. After vaccination, fish were maintained at $25^{\circ} \mathrm{C}$ and fed commercial dry pellets daily.

Analysis of specific antibody levels. For $7 \mathrm{wk}$ postvaccination, 6 fish from each treatment group were assayed for antibody response against OmpU by enzyme-linked immunosorbent assay (ELISA) every week. The wells of 96-well plates were coated with the isolated OmpU $\left(10 \mu \mathrm{g} \mathrm{ml}^{-1}\right)$. Fish serum samples (antibodies) of various dilutions were added to the microtiter plate, which had been blocked with $2 \%$ BSA. Antibody binding to the antigen was detected using rabbit antiserum against the isolated OmpU. Finally, plates were incubated with goat anti-rabbit IgG horseradish peroxidase (HRP) conjugate. The reaction was developed with the 3,3,5,5-tetramethylbenzidine (TMB) substrate in $\mathrm{H}_{2} \mathrm{O}_{2}$ and stopped with $2.0 \mathrm{M}$ $\mathrm{H}_{2} \mathrm{SO}_{4}$. Optical density was measured at $450 \mathrm{~nm}$ using a microplate reader ( $\mu$ Quart, BioTek).

Bacterial challenge experiments. Virulent Vibrio alginolyticus strain HY9901 was cultured at $28^{\circ} \mathrm{C}$ in TSB medium for $18 \mathrm{~h}$. On Day 50 post-immunization, 57 fish from the OmpU vaccination group were divided into 3 sub-groups. All sub-groups and the negative control group were then anaesthetized and challenged by intramuscular injection of $0.2 \mathrm{ml} \mathrm{V}$. alginolyticus cell suspension $\left(1 \times 10^{7} \mathrm{CFU} \mathrm{ml}^{-1}\right)$. Each sub-group of fish was then maintained in a separate tank with fresh running water at $25^{\circ} \mathrm{C}$ for $14 \mathrm{~d}$. Dead fish were autopsied to determine the cause of death and to detect the presence of $V$. alginolyticus in the tissues by bacterial culture in thiosulfate citrate bile salts sucrose (TCBS) agar. Relative percentage survival (RPS) was calculated from the cumulative mortalities using:

$$
\text { RPS }=\left(\frac{1-\text { Mortality of vaccinated fish }}{\text { Mortality of control fish }}\right) \times 100
$$

Statistical analysis. Data are expressed as mean \pm SD. Statistical analysis was performed to assess serum antibody levels and mortality for significance $(p<0.05)$ using Duncan's multiple range test approach. Probabilities of 0.05 or less were considered statistically significant.

\section{RESULTS}

\section{Crude OMPs of Vibrio alginolyticus}

The analysis of the crude OMPs by SDS-PAGE showed a complex electrophoretic profile having approximately 4 proteins with molecular masses between 29 and $97.4 \mathrm{kDa}$ (Fig. 1A). The molecular masses of the 4 main proteins were calculated to be $47.8,43.1,39.3$, and $35.6 \mathrm{kDa}$.

\section{Isolation and $\mathrm{N}$-terminal amino-terminal amino acid sequence of the $35.6 \mathrm{kDa}$ OMP}

The $35.6 \mathrm{kDa}$ OMP is a major OMP of Vibrio alginolyticus with an apparent molecular mass of $35.6 \mathrm{kDa}$ in SDS-PAGE (Fig. 1A, Lane 1), and it was isolated by excision from a preparative SDS-PAGE gel. The identity of the eluted material was confirmed by analytical SDS-PAGE, from which a single band of $35.6 \mathrm{kDa}$ was obtained (Fig. 1A, Lane 2). From 56 mg crude OMPs loaded onto the preparative PAGE gel, $1.8 \mathrm{mg}$ of the $35.6 \mathrm{kDa}$ protein was obtained. The $35.6 \mathrm{kDa}$ protein therefore comprises approximately $3.2 \%$ of the total crude OMPs of $V$. alginolyticus.

$\mathrm{N}$-terminal amino acid sequencing was performed in order to compare the $35.6 \mathrm{kDa}$ OMP with known proteins. The sequence of the first 27 amino acid residues

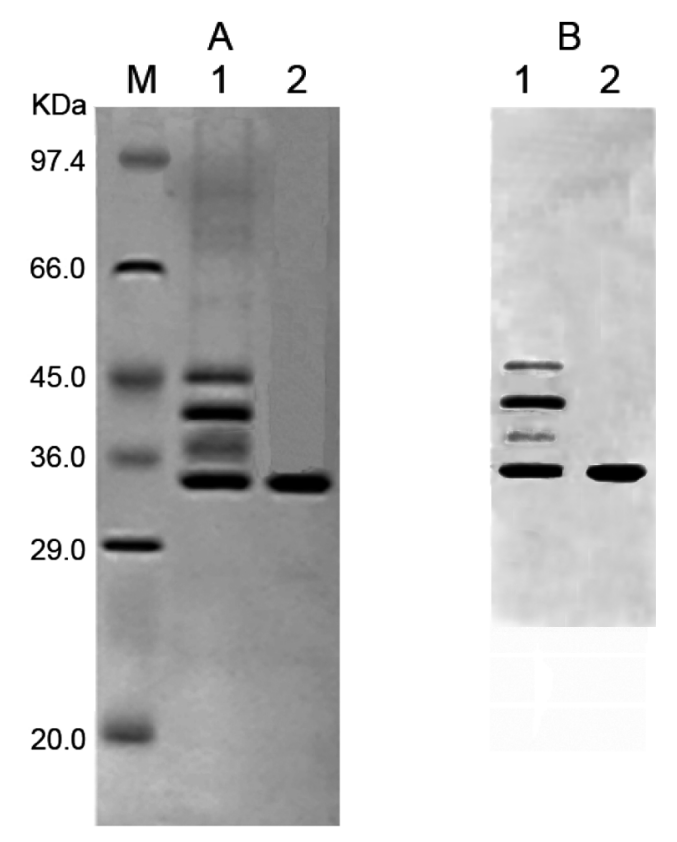

Fig. 1. Vibrio alginolyticus. (A) SDS-PAGE profile of crude outer membrane proteins (OMPs) and major outer membrane protein $\mathrm{OmpU}$, and (B) western blot analysis with anti- $V$. alginolyticus serum. Lanes: $\mathrm{M}$, molecular mass markers; 1 , crude OMPs; 2, the isolated OmpU 
from the N-terminal end of the protein is ATV YKD GGT ELL VGG RVE FRG DFI GSD. A search of the GenBank and BLAST sequence database revealed 92, 88, 88 and $88 \%$ similarity with the OmpU proteins of Vibrio harveyi HY01, V. parahaemolyticus AQ3810, $V$. alginolyticus 12G01, and $V$. campbellii AND4, respectively (Fig. 2).

\section{Immunoreactivity of the OmpU of Vibrio alginolyticus}

To assess the role of the OmpU in the pathogenicity of Vibrio alginolyticus during natural infection, western blotting of crude OMPs and the isolated OmpU with rabbit sera against $V$. alginolyticus was conducted and showed recognition of the OmpU (Fig. 1B, Lanes 1 and 2).

\section{Analysis of serum antibody levels}

The antibody production against the OmpU of Vibrio alginolyticus by Lutjanus erythropterus is shown in Fig. 3. The results show that a specific antibody titer against OmpU was detected in all sera of the vaccinated fish. During Weeks 1 to 10 post-vaccination, $\log _{2}$ (antibody titers) in the sera of the vaccinated group all reached above 5.0, and the maximum reached 14.0, while that of the control group was only 1.0 to 3.0 at all times. Comparison of the means of $\log _{2}$ (antibody titers) between the vaccinated and control groups revealed a statistically significant difference $(p<0.01)$.

\section{Efficacy of the OmpU vaccine}

The cumulative mortality of Lutjanus erythropterus after challenge with virulent Vibrio alginolyticus is shown in Table 1. The fish were immunized with the OmpU vaccine and obtained a high level of protection. The results showed that the fish mortality rate was significantly lower in the vaccinated groups than in the control group after challenge with $V$. alginolyticus $(\mathrm{p}<0.01)$. The tested fish in the control group began to die on Day 2, with a sudden increase in the daily death rate on Days 3 to 6, then a decrease until Day 14. The dead fish showed typical signs of vibriosis, including anorexia, skin ulcers and necrosis of the tail fin and scales and no pathogen other than $V$. alginolyticus was isolated. The RPS value for the OmpU vaccine was 96.43 .

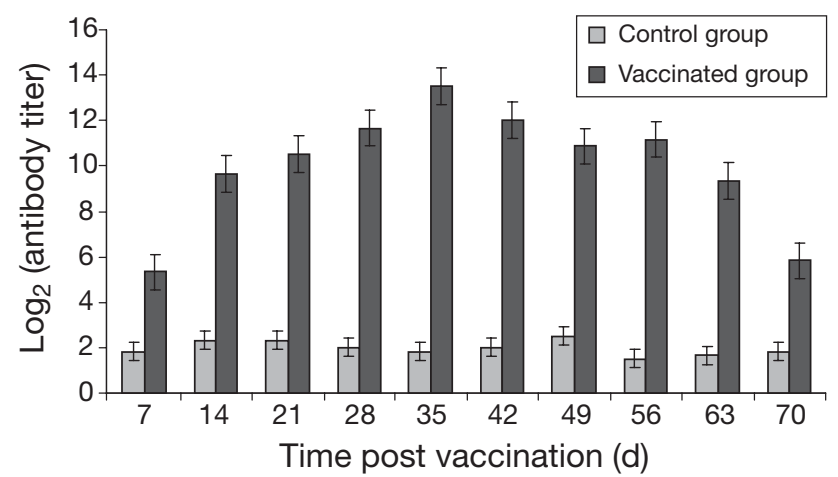

Fig. 3. Analysis of serum antibody levels against OmpU of Vibrio alginolyticus in Lutjanus erythropterus. Each bar represents the $\log _{2}$ value of the highest dilution of the serum pool when $\left(\mathrm{OD}_{450}\right.$ value of the inspected sera $) /\left(\mathrm{OD}_{450}\right.$ value of the negative serum) $>2.9$. Values are significantly different from the control $(p<0.01)$

Table 1. Lutjanus erythropterus infected with Vibrio alginolyticus. Cumulative mortality after challenge

\begin{tabular}{|c|c|c|c|c|}
\hline \multirow{2}{*}{$\begin{array}{l}\text { Days after } \\
\text { challenge }\end{array}$} & \multicolumn{2}{|c|}{ Vaccinated group } & \multicolumn{2}{|c|}{ Control group } \\
\hline & $\begin{array}{c}\text { No. of } \\
\text { dead fish }\end{array}$ & $\begin{array}{c}\text { Mortality } \\
\text { rate (\%) }\end{array}$ & $\begin{array}{c}\text { No. of } \\
\text { dead fish }\end{array}$ & $\begin{array}{c}\text { Mortality } \\
\text { rate (\%) }\end{array}$ \\
\hline 1 & 0 & 0 & 0 & 0 \\
\hline 2 & 0 & 0 & 4 & 7.02 \\
\hline 3 & 0 & 0 & 20 & 35.09 \\
\hline 4 & 0 & 0 & 32 & 56.14 \\
\hline 5 & 0 & 0 & 41 & 71.93 \\
\hline 6 & 1 & 1.75 & 46 & 80.70 \\
\hline 7 & 1 & 1.75 & 47 & 82.46 \\
\hline 8 & 1 & 1.75 & 49 & 85.96 \\
\hline 9 & 1 & 1.75 & 51 & 89.47 \\
\hline 10 & 1 & 1.75 & 52 & 91.23 \\
\hline 11 & 2 & 3.52 & 54 & 94.74 \\
\hline 12 & 2 & 3.52 & 56 & 98.25 \\
\hline 13 & 2 & 3.52 & 56 & 98.25 \\
\hline 14 & 2 & 3.52 & 56 & 98.25 \\
\hline
\end{tabular}




\section{DISCUSSION}

OMPs are important surface materials for bacterial infections. They have multiple functions and roles that help bacteria survive, such as acting as antennae for environmental signals, adhesion for colonization and also as invasion mediators (Beher et al. 1980, Sperandio et al. 1995, Jung et al. 2005). We describe the isolation and characterization of an immunogenic protein from the outer membranes of Vibrio alginolyticus. The OMPs of Gram-negative bacteria are immunologically important because of their accessibility to the host defense system (Hamid \& Jain 2008, Yang et al. 2008). However, there is only relatively limited information available about the potential of OMPs to confer protection against $V$. alginolyticus. The gel excision method was used as the approach of choice for isolation of OmpU because of the relative ease of working with the OMP fraction recovered from the gels. This method has yielded good results in our laboratory.

Some of the important attributes of a candidate molecule for vaccine development are that it should be highly conserved among various members of the same genus, should be expressed on the surface of pathogens so that antigen-presenting cells can easily recognize them, and should be immunogenic (Khushiramani et al. 2007). Vaccination with OmpK and OmpW has been shown to be effective against Vibrio infections in fish (Qian et al. 2007, Li et al. 2008). In the present study, the N-terminal amino acid sequence of the OmpU of $V$. alginolyticus was found to have very high homology with those of other Vibrio $(\leq 92 \%)$ by BLAST analysis. When rabbit polyclonal antibodies against $V$. alginolyticus were tested in western blot with crude OMPs and the isolated OmpU, a strong reaction was observed between the rabbit antiserum and OmpU. This proves that the OmpU of $V$. alginolyticus retained natural antigenicity. Therefore, we presume the OmpU could be used as a potential vaccine candidate.

The present study suggested that a strong antibody response was induced and significant protection was achieved by vaccination with the OmpU of Vibrio alginolyticus in Lutjanus erythropterus. Some studies have also reported that native or recombinant OMPs can induce protective immunity in aquatic animals (Mao et al. 2007, Li et al. 2008, Qian et al. 2008). The native N-lauroylsarcosine-extracted OMP of Edwardsiella ictaluri could partially protect channel catfish from ulcer disease (Bader et al. 2004). Khushiramani et al. (2007) reported that the recombinant OmpTS of Aeromonas hydrophila provided protection for Indian major carp Labeo rohita with a RPS of 57 . Mao et al. (2007) reported that the recombinant OmpK of $V$. parahaemolyticus provided protection for large yellow croaker with a RPS of 90 . Recently, it was shown that the recombinant OmpK of $V$. harveyi could provide protection for orange-spotted grouper with a RPS of 100 (Li et al. 2008). In our study, L. erythropterus vaccinated with the isolated OmpU of $V$. alginolyticus were protected with a RPS of 96.43. The different RPS values reported for outer membrane fraction vaccines probably result from the different amino acid sequences, the different virulence of the bacteria and the different immune tolerance in the tested animals.

Vibrio alginolyticus is one of the main Vibrio pathogens in marine animals, and results in serious economic losses. It is, therefore, desirable to develop an effective vaccine against the disease. Vaccination with OMPs has been shown to be effective against infection by $V$. vulnificus, $V$. anguillarum and $V$. harveyi in fish (Jung et al. 2005, Kumar et al. 2007, Li et al. 2008). The present study indicated that the isolated OmpU is an effective vaccine candidate against infection by $V$. alginolyticus. OmpU gene cloning and over-expression is ongoing.

Acknowledgements. This work was supported by research grants from the National Science \& Technology Pillar Program (No. 2007BAD29B05) in the People's Republic of China. We thank all the people who have dedicated time to these experiments.

\section{LITERATURE CITED}

Aeckersberg F, Lupp C, Feliciano B, Ruby EG (2001) Vibrio fischeri outer membrane protein OmpU plays a role in normal symbiotic colonization. J Bacteriol 183:6590-6597

Bader JA, Shoemaker CA, Klesius PH (2004) Immune response induced by N-lauroylsarcosine extracted outermembrane proteins of an isolate of Edwardsiella ictaluri in channel catfish. Fish Shellfish Immunol 16:415-428

Beher MG, Schnaitman CA, Pugsley AP (1980) Major heatmodifiable outer membrane protein in Gram-negative bacteria: comparison with the ompA protein of Escherichia coli. J Bacteriol 143:906-913

Blum H, Beier H, Gross HJ (1987) Improved silver staining of plant proteins, RNA and DNA in polyacrylamide gels. Electrophoresis 8:93-99

Cai SH, Wu ZH, Jian JC, Lu YS (2007) Cloning and expression of gene encoding the thermostable direct hemolysin from Vibrio alginolyticus strain HY9901, the causative agent of vibriosis of crimson snapper (Lutjanus erythopterus). J Appl Microbiol 103:289-298

- Cheng W, Liu CH, Tsai CH, Chen JC (2005) Molecular cloning and characterisation of a pattern recognition molecule, lipopolysaccharide- and $\beta-1,3$-glucan binding protein (LGBP) from the white shrimp Litopenaeus vannamei. Fish Shellfish Immunol 18:297-310

de la Peña LD, Tamaki T, Momoyama K, Nakai T, Muroga K (1993) Characteristics of the causative bacterium of vibriosis in the kuruma prawn, Penaeus japonicus. Aquaculture 115:1-12

Egidius E (1987) Vibriosis: pathogenicity and pathology. A review. Aquaculture 67:15-28

Gordon LA, Alistair JR (1992) Vaccines, vaccination and the immune response. Lippincott-Raven, San Diego, CA, p 137-143 
Hamid N, Jain SK (2008) Characterization of an outer membrane protein of Salmonella enterica serovar typhimurium that confers protection against typhoid. Clin Vaccine Immunol 15:1461-1471

Hong H, Patel DR, Tamm LK, van den Berg B (2006) The outer membrane protein OmpW forms an eight-stranded betabarrel with a hydrophobic channel. J Biol Chem 281: $7568-7577$

Hong GE, Kim DG, Park EM, Nam BH, Kim YO, Kong IS (2009) Identification of Vibrio anguillarum outer membrane vesicles related to immunostimulation in the Japanese flounder, Paralichthys olivaceus. Biosci Biotechnol Biochem 73:437-439

Jung CR, Park MJ, Heo MS (2005) Immunization with major outer membrane protein of Vibrio vulnificus elicits protective antibodies in a murine model. J Microbiol 43: $437-442$

Khushiramani R, Girisha SK, Karunasagar I, Karunasagar I (2007) Cloning and expression of an outer membrane protein ompTS of Aeromonas hydrophila and study of immunogenicity in fish. Protein Expr Purif 51:303-307

Kumar SR, Parameswaran V, Ahmed VPI, Musthaq SS, Hameed ASS (2007) Protective efficiency of DNA vaccination in Asian seabass (Lates calcarifer) against Vibrio anguillarum. Fish Shellfish Immunol 23:316-326

Laemmli UK (1970) Cleavage of structural proteins during the assembly of the head of bacteriophage T4. Nature 227: 680-685

Lee KK, Yu SR, Chen FR, Yang TI, Liu PC (1996a) Virulence of Vibrio alginolyticus isolated from diseased tiger prawn, Penaeus monodon. Curr Microbiol 32:229-231

> Lee KK, Yu SR, Yang TI, Liu PC, Chen FR (1996b) Isolation and characterization of Vibrio alginolyticus isolated from diseased kuruma prawn, Penaeus japonicus. Lett Appl Microbiol 22:111-114

> Li NQ, Bai JJ, Wu SQ, Fu XZ, Lao HH, Ye X, Shi CB (2008) An outer membrane protein, OmpK, is an effective vaccine candidate for Vibrio harveyi in orange-spotted grouper (Epinephelus coioides). Fish Shellfish Immunol 25: 829-833

Litwin CM, Byrne BL (1998) Cloning and characterization of an outer membrane protein of Vibrio vulnificus required for heme utilization: regulation of expression and determination of the gene sequence. Infect Immun 66:3134-3141

Lowry OH, Rosebrough NJ, Farr AL, Randall RJ (1951) Protein measurement with the Folin phenol reagent. J Biol Chem 193:265-275

Mao Z, Yu L, You Z, Wei Y, Liu Y (2007) Cloning, expression and immunogenicity analysis of five outer membrane proteins of Vibrio parahaemolyticus zj2003. Fish Shellfish Immunol 23:567-575

Olsson JC, Joborn A, Westerdahl A, Blomberg L, Kjelleberg S, Conway PL (1996) Is the turbot, Scophthalmus maximus

Editorial responsibility: David Bruno, Aberdeen, UK
(L.), intestine a portal of entry for the fish pathogen Vibrio anguillarum? J Fish Dis 19:225-234

Olsson JC, Joborn A, Westerdahl A, Blomberg L, Kjelleberg S, Conway PL (1998) Survival, persistence, and proliferation of Vibrio anguillarum in juvenile turbot, Scophthalmus maximus (L.), intestine and faeces. J Fish Dis 21:1-10

> Prayitno SB, Latchford JW (1995) Experimental infections of crustaceans with luminous bacteria related to Photobacterium and Vibrio. Effect of salinity and $\mathrm{pH}$ on infectiosity? Aquaculture 132:105-112

Qian R, Chu W, Mao Z, Zhang C, Wei Y, Yu L (2007) Expression, characterization and immunogenicity of a major outer membrane protein from Vibrio alginolyticus. Acta Biochim Biophys Sin (Shanghai) 39:194-200

Qian R, Xiao Z, Zhang C, Chu W, Mao Z, Yu L (2008) Expression and purification of two major outer membrane proteins from Vibrio alginolyticus. World J Microbiol Biotechnol 24:245-251

Sperandio V, Girón JA, Silveira WD, Kaper JB (1995) The OmpU outer membrane protein, a potential adherence factor of Vibrio cholerae. Infect Immun 63:4433-4438

Towbin H, Staehelin T, Gordon J (1979) Electrophoretic transfer of proteins from polyacrylamide gels to nitrocellulose sheets: procedure and some applications. Proc Natl Acad Sci USA 76:4350-4354

Tsolis RM (2002) Comparative genome analysis of the $\alpha$-proteobacteria: Relationships between plant and animal pathogens and host specificity. Proc Natl Acad Sci USA 99: 12503-12505

> Vandenberghe J, Li Y, Verdonck L, Li J, Sorgeloos P, Xu HS, Swings J (1998) Vibrios associated with Penaeus chinensis (Crustacea: Decapoda) larvae in Chinese shrimp hatcheries. Aquaculture 169:121-132

Waldbeser LS, Tolmasky ME, Actis LA, Crosa JH (1993) Mechanisms for negative regulation by iron of the fatA outer membrane protein gene expression in Vibrio anguillarum 775. J Biol Chem 268:10433-10439

> Wang SY, Lauritz J, Jass J, Milton DL (2003) Role for the major outer membrane protein from Vibrio anguillarum in bile resistance and biofilm formation. Microbiology 149: 1061-1071

Xu C, Wang S, Ren H, Lin X, Wu L, Peng X (2005) Proteomic analysis on the expression of outer membrane proteins of Vibrio alginolyticus at different sodium concentrations. Proteomics 5:3142-3152

Yang Z, Liu Q, Wang Q, Zhang Y (2008) Novel bacterial surface display systems based on outer membrane anchoring elements from the marine bacterium Vibrio anguillarum. Appl Environ Microbiol 74:4359-4365

Zorrilla I, Moriñigo MA, Castro D, Balebona MC, Borrego JJ (2003) Intraspecific characterization of Vibrio alginolyticus isolates recovered from cultured fish in Spain. J Appl Microbiol 95:1106-1116

Submitted: November 10, 2009; Accepted: January 21, 2010 Proofs received from author(s): April 28, 2010 